\title{
ANALYSIS OF PRODUCTION EFFICIENCY OF SHEABUTTER (VITELLARIA PARADOXA) IN OKE OGUN AREA OF OYO STATE
}

\author{
Bolaji-Olutunji K. A, Ugege B.H, Adebayo D.O, Odediran F.A and Adebayo O. \\ Forestry Research Institute of Nigeria, FRIN, Jericho Hill, Ibadan Nigeria. \\ (Correspondent e-mail: tunjikofoworola@yahoo.com 08060477354) \\ DOI: $10.31364 / \mathrm{SCIRJ} / \mathrm{v6.i8.2018.P0818552}$ \\ http://dx.doi.org/10.31364/SCIRJ/v6.i8.2018.P0818552
}

\begin{abstract}
A multi-stage sampling technique was used in selecting respondents for this study. The first stage involved a purposive selection of three Local Government Areas (LGAs) that are known primarily for Shea butter production in the state. In the second stage, two communities were randomly selected from each of the LGAs to arrive at a total of 6 communities. Three Local government areas were selected with a total number of 100 respondents were sampled in the study area. The people used traditional methods of production because of their low level of education (only $1 \%$ of producer respondent had tertiary education) and the high cost of modern technology. The result of the estimates for parameters of the frontier model on the determinants of technical efficiency showed that cost of labour $(\mathrm{P}>0.01)$, fixed variables $(\mathrm{P}>0.05)$ and consumable variables $(\mathrm{P}>001)$ were negatively related to technical efficiency of Shea butter production and were significant at various levels. The significant value of these variables and their negative effects as shown affirmed the fact that these inputs were the major factors driving the technical efficiency of Shea butter production in Oke Ogun areas of Oyo state. The quantity of seed was positively related to technical efficiency and significant at $1 \%$. This indicated that the more the Shea nut availability the higher the technical efficiency of Shea butter production in the study area.
\end{abstract}

Key words: Efficiency, Frontier, Inputs, Production, Producers

\section{Introduction}

Vitellaria paradoxa commonly called Shea tree is one of the trees mostly exploited by rural people. It has enormous economic, medicinal and cultural benefits. The extracted oil serves as food. Vitellaria paradoxa is an important economic tree that plays a vital role in rural livelihood. The different parts of the tree are usually employed in everyday life. The wood of the Shea tree is used for making tools while the roots and bark have medicinal values well as used as pesticides. The sweet pulp of its fruits is a valuable source of energy during the early part of the rainy season. The butter extracted from the kernels is the most important product of Shea tree used in the production of Shea butter. It is frequently used for domestic purposes such as cooking, lightning, production of soap as skin moisturizer (Hall et al., 1996).

Shea nuts is an important non-timber forest products that play major role in economic enhancement of rural community (Adeokun et al., 2002). A large proportion of the rural population earns their livelihood from the extraction and sale of Shea nut products thereby improving quality of life and standard of living of the rural populace (Agbogidi and Okonta, 2003). Carrettle et al (2009) pointed out that the stakeholders involved in the Shea butter processing business include village pickers and post-harvest processors of Shea nuts, local buying agents, rural and urban butter processors. Shea butter extraction processes are in three categories traditional, semi 
mechanized and fully mechanized industrial systems (Addaquay, 2004). Shea butter procedure is quite tedious and time consuming, from collection of the Shea fruits to the production of the end products (Carrettle et al., 2009). A variety of methods are used traditionally to remove the husks. These include trampling, pounding using a mortar and pestle, and cracking between two stones. In extracting the oil from the kernels, it is estimated that $1 \mathrm{~kg}$ of Shea butter takes about 20-30 hours from collection to final product and 8.5-10.0kg of wood fuel. (Garba et al., 2011). This means that the energy input is quite high. The traditional technique of shea butter extraction is time consuming and quite tedious, though shea butter has potential of evolving into a viable export industry since industries in developed countries are expressing their interest in the importation of Shea butter (Harsh,2001). As global demand for Shea buter worths about $\$ 10$ billion and was projected to grow to over $\$ 30$ billion by 2020 . Nigeria's Sheabutter producers have the capacity to earn foreign exchange, reduce poverty, empower women and generate employment through the establishment of Small and Medium Enterprises (SMEs) across the country. In spite of the huge potential that Nigeria possesses in terms of Shea tree resource, production of Shea butter still remains far below demand, both in the local and international markets as the quality of the butter falls below local satisfaction and international standard. This study examine the analysis of production efficiency of sheabutter in Oke-Ogun area of Oyo state.

\section{PROBLEM STATEMENT}

The evaluation of Shea nut processing to the socio - economic development of the rural populace is very important in the Oke- Ogun Area of Oyo State. In literature consumption, production and commercialization have not been given adequate recognition and support, but in recent years, Shea tree has gained importance as an economic tree because of the high demand for its butter both locally and internationally (Fabil, 2007). The Shea butter market is expanding considerably following the European Unions (EU) decision in 2000 to allow up to $5 \%$ of non-cocoa vegetable fat in chocolate manufacturing. Hence, Shea butter has the potential of evolving into a viable export industry since industries in developed countries are expressing their interest in importing in its importation (Harsh, 2001). Inspite of the huge potential that Nigeria possesses in terms of the Shea tree resource, the production of Shea butter still remains far below expectation, the quality of the butter falls below local satisfaction and international standard.

OBJECTIVE: The objectives of the study are to:

1. To profile the socioeconomic characteristic of the producers.

2. Determine production efficiency of Shea butter production in the study area

3. Identify the factors militating against Shea butter production.

\section{JUSTIFICATION}

Shea butter has emerge as a promising economic commodity and has gained international recognition because of its therapeutic properties. The Industry is growing steadily from a small scale activity to a large scale commercial activity. The processing of Shea butter products was found to be profitable as the tree possess positive potentials of enhancing the living standards of farmers. Nigeria, the leading producer of Shea butter in the world with a production capacity of about 600,000 metric tons is yet to fully realize her potentials in the processing and the exportation (Lovett, 2004). Rural livelihoods depend solely on agricultural related activities such as locust bean, honey and Shea butter to mention. The bark, leaves and roots are medicinal, commonly used in curing various illnesses. Despite these potential embedded in Shea tree, its contribution to people's livelihood in the study area is not well research. 


\section{Methodology}

\section{Area of Study}

The study was conducted in Oyo State, Southwestern part of Nigeria between Latitudes $2^{\circ} 38^{1}$ and $4^{0} 35^{1}$ east of kilometers and has a total population of 5,591,589 (NPC, 2006). There are 33 local government areas in the state. It is bordered in the north by Kwara State, east by Osun State and the south by Ogun states. In the west, it is bordered by Ogun state and by the Republic of Benin. The state has an annual rainfall between $1000 \mathrm{~mm}$ and $1400 \mathrm{~mm}$ and has a vast area of fertile land that is suitable for the production of crops such as the vegetables, yam, cassava, cowpea, tomatoes, maize and perennial crops such as Shea nut, Cashew etc. Farming in the state is largely traditional and small scale relying on manual labour involving the use cutlasses and hoes (Ademola et al., 2012).

\section{Sampling procedure and data Collection}

A multi-stage sampling technique was used in selecting respondents for this study. The first stage involved a purposive selection of three Local Government Areas (LGAs) that are known primarily for Shea butter production in the state. In the second stage, two communities were randomly selected from each of the three LGAs to arrive at a total of 6 communities. Three Local government Areas were visited out of which 45 respondents were selected in Atisbo (Tede \& Ago-aare), 30 respondents were selected from Saki East (Oje owode \& Ago-Amodu) and 25 respondents from Saki West (Saki \& Isale oke), based on the proportionate size of Shea butter producers in the study area. A total number of 100 respondents were sampled in the study area. Data were collected on the socio-economic characteristics of the producers, inputs accessibility in Shea butter production and constraints faced by producer among others.

\section{Stochastic Frontier and Efficiency Measurement:}

The measurement of the efficiency of production has been an important area of research over the last two decades. For this purpose stochastic frontier production function has been used. Coelli, (1994) observed that thirty out of forty studies on application of frontier models to agriculture have used stochastic frontier production function. The advantage of using stochastic frontier models are: (1) It introduces a disturbance term representing statistical noise, measurement error and exogenous shocks beyond the control of production units which would other-wise be attributed to technical inefficiency, (2) It provides the basis for conducting statistical tests of hypothesis regarding the production structure and the degree of inefficiency. The estimation of frontier function and efficiency can be completed either in one stage or in two stages. This paper follows the Ndubueze-Ogaraku and Ekine (2015) approach of modeling both the stochastic and the technical inefficiency effects in the frontier, in terms of observable variables, and estimating all parameters by the method of maximum likelihood, in a single-step analysis.

Model and Variables: The Cobb-Douglas (CD) production function was found to be an adequate representation of the data, given the specifications of the corresponding translog frontier model. The stochastic frontier model is defined by:

$\operatorname{In}(Y i)=\beta o+\beta_{1 i} \operatorname{In}\left(X_{1 i}\right)+\beta_{1 i}\left(X_{1 i}\right)+\beta_{1 i}\left(X_{1 i}\right)+V i+U i$

Where ln represents the natural logarithm (base, e); the subscript, I denotes the i-th farmer in the sample, $\mathrm{I}=1,2,3, \ldots 99$;

$$
\begin{array}{lll}
\mathrm{Y}_{\mathrm{i}} & = & \text { Shea butter output } \\
\mathrm{X}_{1 \mathrm{i}} & = & \text { represents the labour cost }( \\
\mathrm{X}_{2 \mathrm{i}} & = & \text { represent transportation cost }(
\end{array}
$$




$$
\begin{array}{lll}
\mathrm{X}_{3 \mathrm{i}} & = & \text { represent the fixed cost }(\mathrm{A}) \\
\mathrm{X}_{4 \mathrm{i}} & =\quad \text { consumable cost }(\mathrm{N})
\end{array}
$$

Vi's are random errors associated with measurement errors in the production of Shea butter reported, or the combined effects of input variables not included in the production function, whereas $\mathrm{Vi}$ 's are assumed to be independently and identically distributed $\mathrm{N}\left(\mathrm{o} \sigma \mathrm{v}^{2}\right)$ random variable; the i U's are non-negative random variables, associated with technical inefficiency of production of the farmers, assumed to be independently distributed, such that the technical inefficiency effect for the ith producer, Ui is obtained by truncation (at zero) of the normal distribution with mean mi and variance $\sigma^{2}$ such that

$\mathrm{mi}=\delta_{0}+\delta_{1} \mathrm{Z}_{1 \mathrm{i}}+\delta_{2} \mathrm{Z}_{1 \mathrm{i}}+\delta_{3} \mathrm{Z}_{1 \mathrm{i}}+\delta_{4} \mathrm{Z}_{1 \mathrm{i}}+\delta_{5} \mathrm{Z}_{1 \mathrm{i}}$

Where

$\mathrm{Z}_{\mathrm{ii}} \quad=\quad$ age of the producer in years

$\mathrm{Z}_{2 \mathrm{i}} \quad=\quad$ marital status

$\mathrm{Z}_{3 \mathrm{i}} \quad=\quad$ education in years

$\mathrm{Z}_{4 \mathrm{i}} \quad=\quad$ household size

$\mathrm{Z}_{5 \mathrm{i}} \quad=\quad$ year of experience

\section{RESULTS AND DISCUSSION}

Gender: Majority (75.8\%) of the respondents were females while $24.2 \%$ were males. This is because the process involved in the production of Shea butter attracts more females, while the males were more involved farming activities than Shea butter processing. This finding is in line with Jamala et al., (2013), that the possible reasons maybe due to the nature and operations involved in the production processes in Shea butter. This is also confirmed by Carrettle et al., (2009) that shea butter business is women's.

Marital Status: Majority (90.9\%) of the respondents were married while few (4.0\%) of the respondents were either single or widowed. This is because shea butter improves the quality of life and standard of living of rural population as observed by Agbogidi and Okonta, (2003).This is because the married respondents will derive support from their family members in Shea butter processing.

Education: The result indicated that $17.2 \%$ of the shea butter producer had no formal education, $45 \%$ had primary education, $27.3 \%$ had secondary education while $1 \%$ of the respondent had Tertiary and others education. This implies that majority of shea butter producer had low educational status which could affect their level of adoption of new technology. This agrees with Schreckenberg K (2004) findings which said that it would be difficult for those that had low formal education in shea butter business to adopt modern techniques, innovation or new idea in their production.

Occupation: Majority (91.9\%) of the respondents were strictly involved in the enterprise of Shea butter production while the remaining were artisan (1.0\%), civil service (2\%), trading (4.0\%). This implies that respondents in the study area were strictly involved in the business as a means livelihood. The study discovered that the sheanut is available throughout the year so the producers 
are occupied with their processing. This study is in line with Ademola and Oyesola, (2012), that majority of the processors have their primary occupation to be Shea butter processing, showing the level of devotion to the vocation in the area.

\section{Years of experience:}

The distribution of the experience reveals that $11.4 \%, 33.1 \%, 32.7 \%, 18.1 \%$ and $4.7 \%$ of the respondents had years of experience range 1-5 years, 6-10 years, 11-15 years, 16-20 years and greater than or equal to 21 years, respectively. This implies that majority (33.1\%) of the processors had between 6 and 10 years of experience. This is confirmed by Koloche, et al., (2016) that Shea nut processors in Oke-Ogun areas had acquired enough processing experience that will encourage them to adopt improved Shea nut processing technologies.

\section{Factors militating against Shea butter production:}

Majority (87.9\%) of the respondents in the study area were involved in indiscriminate felling of charcoal production. This is because Shea tree (Vitellaria paradoxa) is one of the trees for good quality charcoal production. This finding is in line with Tunde et al (2013) that Vitelleria paradoxa has good quality that can be used for charcoal production. This implies that there are alternatives uses of shea butter trees that are competing with shea butter production.

Shelf life: Most (58.6\%) of the respondents indicated that Shea butter shelf life is between 3-4 years while $28.3 \%$ of the respondent indicated that Shea butter shelf life can stay for 5 years. This implies that shea butter does not get spoilt quickly, as a result of this, it can be kept for a long time. Its unique characteristic (shelf life) encourages the marketing and storage.

Table 1: Socio-economic characteristics of the respondents

\begin{tabular}{|c|c|c|}
\hline Variable & Frequency & Percentage \\
\hline \multicolumn{3}{|l|}{ Gender } \\
\hline Male & 24 & 24.2 \\
\hline Female & 75 & 75.8 \\
\hline Total & 99 & 100 \\
\hline \multicolumn{3}{|l|}{ Marital status } \\
\hline Single & 4 & 4.0 \\
\hline Marital & 90 & 90.9 \\
\hline Divorce & 1 & 1.0 \\
\hline Widowed & 4 & 4.0 \\
\hline Total & 99 & 100 \\
\hline \multicolumn{3}{|l|}{ Occupation } \\
\hline Sheabutter producer & 91 & $91-9$ \\
\hline Artisan & 1 & 1.6 \\
\hline civil service & 2 & 2.0 \\
\hline Trading & 4 & 4.0 \\
\hline Others & 1 & 1.0 \\
\hline Total & 99 & 100 \\
\hline \multicolumn{3}{|l|}{ Educational status } \\
\hline No formal education & 17 & 17.2 \\
\hline Primary & 45 & 45.5 \\
\hline Secondary & 27 & 27.3 \\
\hline Tertiary & 9 & 9.1 \\
\hline Others & 1 & 1 \\
\hline Total & 99 & 100 \\
\hline \multicolumn{3}{|l|}{ Experience(Years) } \\
\hline $0-10$ & 24 & 24.2 \\
\hline $11-20$ & 20 & 20.2 \\
\hline
\end{tabular}




\begin{tabular}{|lll|}
\hline $21-30$ & 26 & 26.3 \\
$31-40$ & 20 & 20.2 \\
$41-50$ & 6 & 6.1 \\
$51-60$ & 3 & 3.0 \\
Total & $\mathbf{9 9}$ & $\mathbf{1 0 0}$ \\
\hline
\end{tabular}

Source: Data Analysis, 2017

Table 2: Socio-economic characteristics of the respondents (Cont'd)

\begin{tabular}{|lll|}
\hline Variable & Frequency & Percentage \\
\hline Production frequency & 1 & 1.0 \\
Daily & 49 & 49.5 \\
Weekly & 40 & 40.4 \\
Fortnightly & 9 & 9.1 \\
Monthly & $\mathbf{9 9}$ & $\mathbf{1 0 0}$ \\
Total & & \\
Markets & 19 & 19.2 \\
Wholesaler & 1 & 1.0 \\
Final Consumer & 1 & 1.0 \\
Retailer & 78 & 78.8 \\
All of the above & 99 & 100 \\
Total & & \\
Shell Life & 12 & 12.1 \\
2 & 29 & 21.3 \\
3 & 29 & 39.0 \\
4 & 28 & 28.2 \\
5 & 1 & 1.0 \\
6 & $\mathbf{9 9}$ & $\mathbf{1 0 0}$ \\
Total & & \\
Market Accessibility & 96 & 97.0 \\
Local & 2 & 2.0 \\
International & 1 & 1.0 \\
Both & $\mathbf{9 9}$ & $\mathbf{1 0 0}$ \\
Total & &
\end{tabular}

Source: Data Analysis, 2017

Table 3. Sources of collection of Vitelleria paradoxa in the study area

\begin{tabular}{ll}
\hline Source & $\%$ \\
\hline Personal farm & 3.0 \\
Community farm & 1.0 \\
Forest & 12.1 \\
Buying & 83.8 \\
Total & 100.0 \\
\hline
\end{tabular}

Source: Data analysis, 2017 
Table 3, presents the results of the source of seed collection in the study area. About 12.1\%, 1.0\% and 3.0\% of them sourced from the forests, community farm and personal farm respectively while majority (83.8\%) of the respondents sourced sheanuts from other sources such as buying from local and neighbouring markets. This implies that other sources constituted the major source of seed in the study area.

Table 4. Source of purchase of Vitelleria paradoxa in the study area

\begin{tabular}{ll}
\hline Source & $\%$ \\
\hline Local market & 76.8 \\
Inter-state market & 5.1 \\
All of the above & 6.1 \\
Farm gate and local market & 12.1 \\
Total & 100.0 \\
\hline
\end{tabular}

Source: Data analysis, 2017

Table 4 revealed that source or place of purchase of the seeds in the study area. The results shows that majority (76.8\%) of the respondents purchased seeds from the local market while $5.1 \%$ and $12.1 \%$ of them bought from inter-state market and farm gate/local market respectively. However, $6.1 \%$ of them purchased from both local and inter states markets. This implies that the major place of purchase in the area was the local market and this agrees with the findings of Ademola and Oyesola, (2012) that shea butter was in abundant supply in the area.

Table 5. Seasons for Vitelleria paradoxa collection in the study area

\begin{tabular}{ll}
\hline Season & $\%$ \\
\hline Yes & 99.0 \\
No & 1.0 \\
Total & 100.0 \\
\hline
\end{tabular}

Source: Data Analysis, 2017 
Most of the respondents $(98 \%)$ confirmed that collection of Vitelleria paradoxa is seasonal (Table 5). But always thrive well and abundance in harvest that processing was throughout the year.

Table 6. Membership of association in the study area

\begin{tabular}{ll}
\hline Variable & $\%$ \\
\hline Yes & 72.7 \\
No & 27.3 \\
Total & 100.0 \\
\hline
\end{tabular}

Source: Data Anaysis, 2017

Table 6 shows that majority $(72.7 \%)$ of the respondent producers belonged to an association while few (27.3\%) did not belong to any association in the study area.

Table 7. Price determinants of Vitelleria paradoxa in the study area

\begin{tabular}{ll}
\hline Variable & $\%$ \\
\hline Individually & 29.3 \\
Association & 69.7 \\
Others & 1.0 \\
\hline
\end{tabular}

Source: Field survey, 2017

Table 7 shows the result of the price determinants of Vitelleria paradoxa in the study area. According to the results, majority (69.7\%) of the respondents revealed that association determines prices of Vitelleria paradoxa are to be sold in the market while $29.3 \%$ of them indicated that individuals determined price in the market. It could be agreed upon that association is the major determinant of product price in the area.

Table 8. Processing methods of Vitelleria paradoxa in the study area

\begin{tabular}{lc}
\hline Variable & $\%$ \\
\hline Local method & 98.0 \\
Modern method & 1.0 \\
Both & 1.0 \\
\hline
\end{tabular}


Source: Data analysis, 2017

Table 8. shows the pr6ocessing method of Vitelleria paradoxa in the study area, which reveals that majority (98\%) of the respondents indicated that they used local processing method while just $1 \%$ used modern processing methods. This implies that local processing method is still mainly used in the study area. This agrees with the findings of Ademola and Oyesola, (2012), also, of Dauda et al; (2014), that Shea butter is still mostly made in the traditional way by women who learned the methods from their elders, which have been handled down to generations. This method is characterized by low quality, low quantity and the technical inefficiency (Carette $e t$ al., 2009).The reason for using this local method could be that the modern technology is expensive which is in line with the findings of Dauda et al., (2014), that the inputs required for modern technology are quite costly and in most cases are beyond the reach of producers as they do not have adequate capital to purchase these vital logistics.

\section{Determination of Technical Efficiency of Shea butter Production Using Stochastic Frontier Functions}

The maximum likelihood estimates of the parameters of the stochastic frontier production function defined by equation (1) and (2) are presented in Table 9.The estimate for the variance parameter, $\sigma^{2} / \sigma s^{2}$ indicates that the variance, $\sigma^{2}$ associated with the inefficacy effect is about $2 \%$ of the two variances. Estimated output elasticities for all the inputs all differed from zero at the $5 \%$ significance level.

The result of the estimates for parameters of the frontier model on the determinants of technical efficiency showed that cost of labour $(P>0.01)$, fixed variables $(P>0.05)$ and consumable variables $(P>001)$ were negatively related to technical efficiency of Shea butter production and were significant at various levels. The significant value of these variables and their negative effects as shown affirmed the fact that these inputs were the major factors driving the technical efficiency of Shea butter production in Oke - Ogun areas of Oyo state.

The quantity of seed was positively related to technical efficiency and significant at $1 \%$. This indicated that the more the Shea nut availability the higher the technical efficiency of Shea butter production in the study area. More so, the study discovered that there were many trees of Shea nuts in the area and high influx of Shea nut in most markets and neighbouring communities in the area.

Their respective elasticities with respect to the output of Shea butter production in the area were $0.31,0.03$ and 0.35 for cost of labour, fixed variable and consumable variables. They had negative signs, which were in line with a priori expectations. It was expected that cost of production should be minimized to maximise output and profit. The seed quantity elasticity with respect to output was 1.46. This implies that the cost of resource inputs was contributing positively to the increase in technical efficiency of Shea butter in OkeOgun.

The result in Table 9. further shows the determinants of technical inefficiency of Shea butter production in Oke-Ogun area. The results indicated that none of the variables included in the model exerted a significant relationship on the technical inefficiency of production technology (Ndubueze-Ogaraku and Ekine 2015, Hossain et al., 2015). This could mean that the variables that could explain efficiency among producers were probably omitted from the model according to Hossain et al., (2015). In further studies, the socio-economic variables to be studied need to be expanded. The foregoing leads us to accept the null hypothesis, Ho, which held that "Shea butter production in the study area is not affected by socioeconomic variables of the producers" especially concerning the socio-economic variables included in the inefficiency model estimated in this study. The estimated lambda parameter of the model was 0.02 , which indicates that about $2 \%$ of the total variation in shea butter output among the producers could be attributed to differences in their technical efficiencies. 
Table 9. Determination of Technical Efficiency of Shea butter Production Using Stochastic Frontier Functions

\begin{tabular}{|c|c|c|c|c|}
\hline Variable & $\begin{array}{l}\text { Parameter } \\
\text { Coefficient }\end{array}$ & Standard Error & $\mathbf{P}>|\mathbf{Z}|$ & \\
\hline Labour cost & -0.3130 & 0.0108 & 0.004 & \\
\hline Transportation & -0.0606 & 0.0759 & 0.425 & \\
\hline Fixed cost & -0.0349 & 0.0167 & 0.037 & \\
\hline Consumable cost & -0.3506 & 0.0780 & 0.000 & \\
\hline Quantity of seed & 1.4666 & 0.0809 & 0.000 & \\
\hline \multicolumn{5}{|l|}{ Inefficiency Model } \\
\hline Constant & 4.2711 & 0.2162 & 0.000 & \\
\hline Age & 0.0427 & 0.0328 & 0.194 & \\
\hline Marital status & -0.0212 & 0.0277 & 0.436 & \\
\hline Education (years) & 0.0129 & 0.0129 & 0.315 & \\
\hline Household size & -0.0278 & 0.0205 & 0.176 & \\
\hline Years of Experience & -0.0069 & 0.0121 & 0.570 & \\
\hline \multicolumn{5}{|l|}{ Variance Parameters } \\
\hline Sigma Squared & 0.0004 & 0.0001 & & \\
\hline Lambda & 0.0225 & 0.0190 & & \\
\hline Log Likelihood Function & & & & 248.49 \\
\hline Log Likelihood ratio & & & & 0.28 \\
\hline
\end{tabular}

Source: Data Analysis, 2017

\section{Conclusion and Policy Recommendation}

The research found that shea butter production was an important occupation in Oke-Ogun Area of Oyo State, Nigeria since $91.9 \%$ of the producer had it as their primary occupation. The production was found to be all y 
ear round because the sheanut was always available to be bought in and out of season. The people used traditional methods of production because of their general low level of educational status and high cost of modern technology. It was found that the cost of labour, fixed variables and cost of consumable variables were significant factors driving the technical efficiency of shea butter production in Oke-Ogun, Oyo state. It is therefore recommended that provision of modern technology to improve on the quality of sheabutter should be provided and the producers need more formal education.

\section{REFERENCES}

Adeokun, O.A.(I988) Newspaper's agricultural agenda setting: A study of selected newspapers and extension agents of Ogun State Phased Agricultural Development Project. Unpublished Masters Dissertion, University of Ibadan, Nigeria.

Ademola, A.O. Oyesola, O.B. Osewa, S.O. (2012). Assessment of shea butter processing among rural dwellers in Atisbo local

Government area of Oyo state, Nigeria. European Journal of Business and Social Sciences, Vol.1 (6), p 1-8. Available on http://www.ejbss.com/recent.aspx

Agbogidi, O.M. and Okonta, B.C. (2003). Role of Women in Community Forestry and Environmental Conservation. In Akindele, S.O. and Popoola, L. (Eds). Proceedings of the 29thAnnual Conference of the Forestry Association of Nigeria (FAN), Calabar, Cross River State, Nigeria. 6th-11thOctober (pp. 159 -165).

Carette, C., Malotaux, M. \& van Leeuwen, M. \& Tolkamp, M. (2009). Sheanut and butter in Ghana. Opportunities and constraints for local processing.University of Wageningen.

Coelli, T.J (1994). A Guide to frontier 4.1: A Computer program for stochastic frontier production and Cost Function Estimation. Department of Econometrics, University of New England, Armidale. NSW 2351.

Dauda S, Adjei Mensah C, Nutsugbodo RY (2014). Urban Poverty in Northern Ghana: Tracing the Livelihood Strategies of Women in the Shea Butter Industry. J. Hum. Soc. Sci. Res. 3(1):15-25.

Fabil, J.N., 2010. Research and Development of the Shea Tree and its Products. HORIZON International, New Haven, USA..

Garba, I.D., Sanni, S.A., and Adebayo, C.O 2015: Analysing the structure and performance of shea butter market in Bosso and Borgu Local Government Area of Niger state : International Journal of u and e service, science technology Vol .8(2), pp 321-336.

Hall JB, Aebischer DP, Tomlinson HF, Osei-Amaning E, Hindle JR (1996) Vitellaria paradoxa. School of Agricultural and Forest Sciences. Publication Number 8, University of Wales.

Hossain, M., Md. Alam, A and Uddin, K. (2015). Application of Stochastic Frontier Production Function on Small Banana Growers of Kushtia District in Bangladesh. Journal of Statistic, Application and Probability. Vol.4 (2), pp.337-342

Koloche, I.M., Olaleye, R.S., Adeniji, O.B., Yahaya, S.A., Umar, S.I., and Tsado, J.H (2016). Adoption of the improved Shea nut processing technologies in Niger State, Nigeria.

Lovett, P. N. 2004. The Sheabutter value chain: production, transformation and marketing in West Africa. West Africa Trade Hub (WATH) Technical Report No. 2. US-AID West Africa Programme.

www.scirj.org

C 2018, Scientific Research Journal

http://dx.doi.org/10.31364/SCIRJ/v6.i8.2018.P0818552 
Jamala, G.Y, Jada, M.Y., Yidau, J. J. and Joel, L., (2013). Socio-Economic Contribution of Shea Tree (Vitellaria paradoxa) in Support of Rural Livelihood in Ganye. Journal of Environmental Science, Toxicology and Food Technology.Vol.6 (5), p.75. Available on www.iosrjournals.org.

Ndubueze-Ogaraku, M. E. and Ekine, D.I.(2015). Application of the Stochastic Production Frontier Function Model to Cassava Production in the Floodplain Area of Rivers State, Nigeria. Journal of Biology, Agriculture and Healthcare, Vol.5, No.4. Retrieved from:www.iiste.org ISSN 2224-3208 (Paper) ISSN 2225-093X (Online).

Schreckenberg K (2004) The contribution of shea butter (Vitellaria paradoxa C.F. Gaertner) to local livelihoods in Benin. In: Sunderland T, Ndoye O (eds). Forest products, livelihoohs and conservation. Indonesia Printer, Indonesia

Tunde, A. M., Adeleke, E. A. \& Adeniyi, E. E. (2013). Impact of Charcoal Production on the Sustainable Development of Asa Local Government Area, Kwara State, Nigeria. International Multidisciplinary Journal Ethiopia. Vol.7 (2), DOI: http://dx.doi.org/10.4314/afrrev.7i2.1 